\title{
Effects of Habitat Restoration on Fish Communities in Urban Streams
}

\author{
Anna M. Lavelle ${ }^{1,2, *}$, Michael A. Chadwick ${ }^{1}$, Daniel D. A. Chadwick ${ }^{3}$, Eleri G. Pritchard ${ }^{3}$ and Nicolas R. Bury ${ }^{4,5}$ \\ 1 Department of Geography, King's College London, Bush House, North East Wing, 40 Aldwych, \\ London WC2B 4BG, UK; Michael.chadwick@kcl.ac.uk \\ 2 Arup Group, Rose Wharf, 78 East Street, Leeds LS9 8EE, UK \\ 3 Environmental Change Research Centre, Department of Geography, University College London, \\ North West Wing Building, Gower Street, London WC1E 6BT, UK; daniel.chadwick.14@ucl.ac.uk (D.D.A.C.); \\ eleri.pritchard.15@ucl.ac.uk (E.G.P.) \\ 4 School of Science, Technology and Engineering, University of Suffolk, Ipswich IP4 1QJ, UK; n.bury@uos.ac.uk \\ 5 Suffolk Sustainability Institute, University of Suffolk, Ipswich IP4 1QJ, UK \\ * Correspondence: anna.lavelle@arup.com
}

check for updates

Citation: Lavelle, A.M.; Chadwick, M.A.; Chadwick, D.D.A.; Pritchard, E.G.; Bury, N.R. Effects of Habitat Restoration on Fish Communities in Urban Streams. Water 2021, 13, 2170. https://doi.org/10.3390/w13162170

Academic Editors: Judy England, Robert Grabowski and Marc Naura

Received: 11 June 2021

Accepted: 26 July 2021

Published: 7 August 2021

Publisher's Note: MDPI stays neutral with regard to jurisdictional claims in published maps and institutional affiliations.

Copyright: (c) 2021 by the authors. Licensee MDPI, Basel, Switzerland. This article is an open access article distributed under the terms and conditions of the Creative Commons Attribution (CC BY) license (https:/ / creativecommons.org/licenses/by/ $4.0 /)$.
Abstract: Geomorphological alterations, hydrological disconnectivity and water pollution are among the dominant pressures affecting ecological integrity in urban streams. River restoration approaches often involve utilising in-stream structures to encourage flow heterogeneity and promote habitat diversity. However, few studies examine the success of such projects. In this study, fish density, biomass and community structure at paired restored and unrestored reaches across five tributaries of the River Thames were examined. Fish density varied among rivers and reaches but was generally higher at restored sites. Restored sites also exhibited higher overall fish biomass, attributed mainly to the presence of brown trout (Salmo trutta L.) at the River Wandle. Despite higher density and biomass values at restored sites, the community structure analysis did not identify strong links between either river or restoration status using either species-specific density or biomass. Our results highlight that although reach-scale restoration can lead to localised increases in species density and biomass, this may chiefly be due to aggregation owing to preferential habitats created through restoration activities at these sites. Over larger spatial scales, significant improvements to species richness and diversity are likely to be limited due to the poor water quality and disconnected nature of these urban streams. Whilst reach-scale restoration clearly has the potential to provide preferential habitats for fish species, future efforts should focus on improving connectivity for fish across the wider Thames basin network by removing barriers to passage, improving water quality, restoring watershed processes and creating well-connected, diverse habitats which can facilitate the survival of a wide array of fish species throughout their life cycle.

Keywords: urban rivers; urban fish communities; river restoration; River Thames catchment

\section{Introduction}

Urbanisation impacts stream fish, which can result in alterations to assemblage structure [1-3]. The drivers of these changes are symptomatic of the urban stream syndrome [4-6] and include modified hydrology [1,7], degraded water quality [8-10] and barriers to migration $[11,12]$. To ameliorate these negative impacts, restoration projects are often used to improve the condition of degraded river systems [13-15].

Reach-scale restoration projects often involve altering channel geomorphology and modifying flow dynamics to mimic natural or pre-degradation habitat conditions [16,17]. Such focus on habitat heterogeneity reflects the assumption that habitat complexity can foster the re-colonisation of aquatic organisms - the "field of dreams hypothesis" [18]. Ecologically focused river restoration projects can involve utilising in-stream structures, such as large wood [19], boulders [20] and gravels [21], to engineer flows, regulate sediment transport, promote oxygenation and improve water quality [22] and habitat diversity [23]. The 
removal of weirs [24], engineering of fish passes [25] and utilisation of flow deflectors [26] are also common approaches used to increase river connectivity, improve in-channel habitats and restore ecosystem functions.

Restoration projects often focus on improving habitat heterogeneity and spawning habitats [27]; however, the response of fish assemblages can be variable [28-30]. For example, restoration can result in more variable water depths and velocities, which, in turn, can lead to increased numbers of both pelagic and benthic fish [31,32]. However, other studies show that restoration can have mixed impacts on habitat quality, where initial habitat improvements to a weighted usable area (WUA) and foraging positions (FP) can subsequently be followed by declines in these indices [33]. Some studies have cautioned against using physical river improvements to predict restoration success due to the weak responses between fish fauna and rehabilitation [34]. Moreover, restoration may lead to the aggregation of fish in and around the improved area rather than resulting in widespread habitat improvements [35]. In the long term, this can lead to challenges for creating effective restoration strategies [28] that promote longer-term recovery. Reconnecting isolated habitats and improving critical habitats (e.g., spawning grounds), rather than focusing efforts on a single species or river reach, may be more effective for increasing fish abundance [36].

River restoration is a common management approach, often aimed at restoring ecosystem function and diversity [37]. Despite this emphasis, uncertainty over the ecological success of restoration efforts remains, and more research is needed to understand the links between physical stream structure, hydrological characteristics and ecological responses following restoration in urban streams. The aim of this study was to assess the benefits of reach-scale restoration on fish assemblages across restored and unrestored tributaries of the River Thames, within the Greater London area. To achieve these aims, we examined how reach-scale restoration affected fish density, biomass and overall community structure.

\section{Materials and Methods}

\subsection{Sampling Area Description}

Paired restored and unrestored reaches from 5 urban tributaries of the River Thames (Brent, Hogsmill, Pool, Ravensbourne and Wandle) were selected for this study from the River Restoration Centre (RRC) database [38] and from previous work ([39] Figure 1, Table 1). The paired 25-metre reaches varied in terms of urban cover, land use and restoration practice. The reaches were spaced approximately 50-250 m apart. On the River Brent and Wandle, the restored reaches were located downstream, whereas, on the Pool, Ravensbourne and Hogsmill, the restored reaches were located upstream.

These rivers were historically channelised, culverted, impounded and polluted, with relics of these impacts still evident today across the wider river networks. The restoration aims for each river were variable, although most were focused on increasing flow heterogeneity and enhancing habitat diversity through the implementation of in-channel structures such as woody debris, berms and recycled crushed concrete. On both the River Wandle and Hogsmill River, larger-scale weir removal efforts to enhance longitudinal connectivity and facilitate fish passage had been accompanied by reach-scale efforts to create flow diversity (through channel narrowing and in-stream vegetation) and variable habitat conditions. The general physical characteristics (e.g., wetted width, depth and flow velocity) obtained within the sampling season (measured at $5 \mathrm{~m}$ intervals throughout each reach) differed across the study rivers and reaches (Table 2). However, the conditions satisfied the environmental requirements expected for resident fish species [40].

\subsection{Field Surveys}

Fish sampling was carried out over a $25 \mathrm{~m}$ stretch of river, as the restoration covered at least $25 \mathrm{~m}$ of bank length at all restored sites. This prevented the inclusion of any unrestored sections in 'restored' sites. Stop nets (10 $\mathrm{mm}$ mesh) were deployed at either end of the reach to create a closed population and prevent fish migration. Sampling was conducted with a backpack electrofisher (Smith Root LR-20B) using a 3 sweep, catch-depletion method. The 
electrofisher was set at $40 \mathrm{~Hz}$ and 150-200 v with settings adjusted for conductivity ( $\sim 590$ to $730 \mu \mathrm{s} \mathrm{cm}^{-1}$ ). To standardise effort, each sweep was conducted for $\sim 600 \mathrm{~s}$ (i.e., the time when electrical current from the backpack unit was on) at all reaches. All fish were identified to species level, measured for total length $(\mathrm{mm})$ and weight $(\mathrm{g})$ and returned below the downstream limit of the stop nets following each sweep. Surveys were carried out in the early autumn (September-October 2016). All sampling was undertaken during clear weather when rivers were not in flood or experiencing rising levels. Surveys were also undertaken within the index period the Environment Agency uses to assess fish. All sampling was biosecure and was conducted under FR2 licensing issued by the UK Environment Agency.

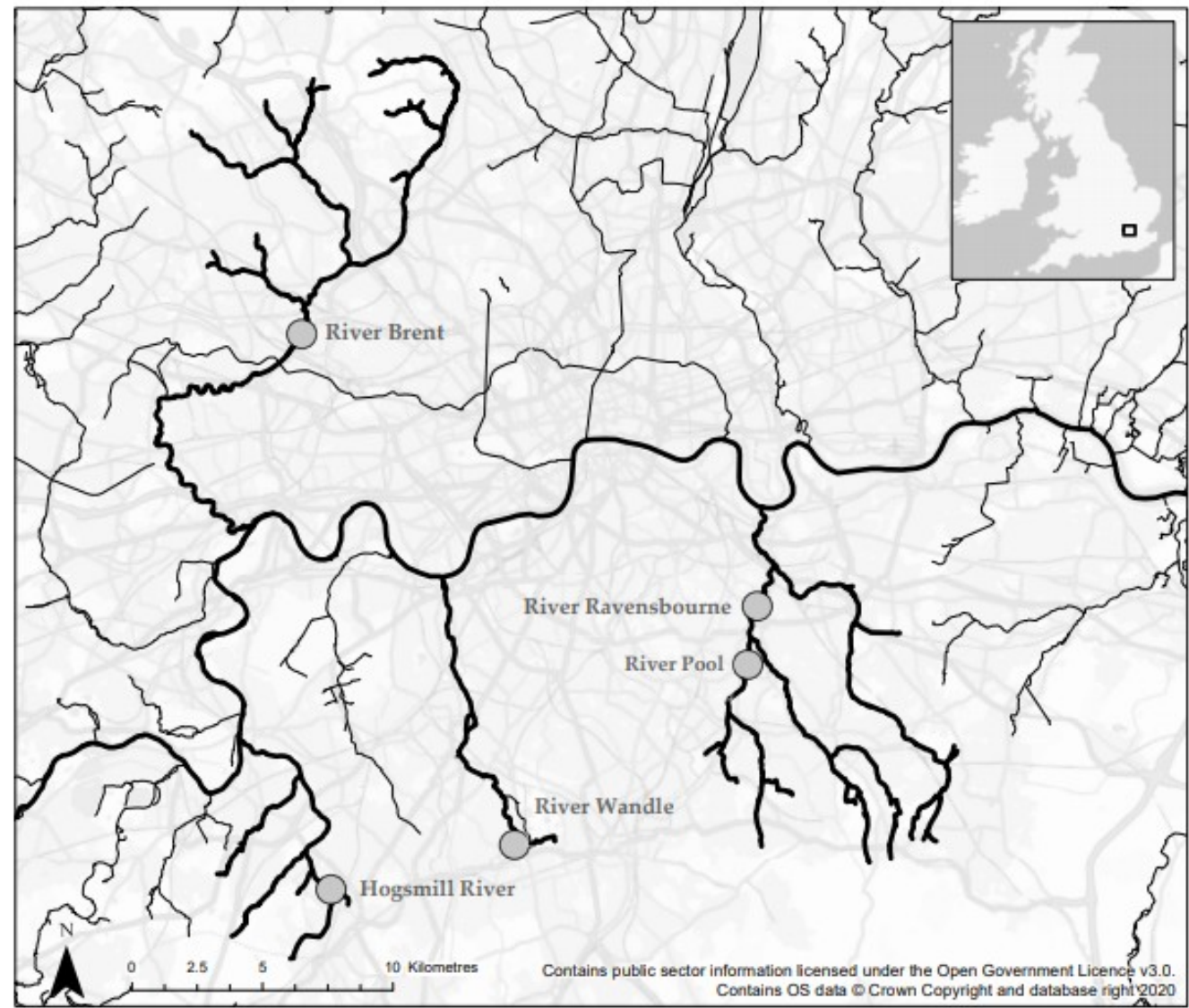

Figure 1. Locations of study rivers across the Greater London area. Bold lines denote study rivers; fine lines denote other watercourses within the wider River Thames network.

Table 1. Characteristics of restoration among the study rivers, including the upstream location of restored and unrestored reaches (degrees, minutes, seconds for latitude and longitude), year of restoration completion, total river length and \% of urban catchment cover [38,39,41,42].

\begin{tabular}{|c|c|c|c|c|c|c|c|c|}
\hline River & Site & $\begin{array}{l}\text { Restored } \\
\text { Upstream } \\
\text { Location }\end{array}$ & $\begin{array}{l}\text { Unrestored } \\
\text { Upstream } \\
\text { Location }\end{array}$ & $\begin{array}{c}\text { Year } \\
\text { Completed }\end{array}$ & $\begin{array}{c}\text { Length } \\
(\mathrm{Km})\end{array}$ & $\begin{array}{l}\% \text { Urban } \\
\text { Catchment } \\
\text { Cover }\end{array}$ & Urban Pressures & Restoration \\
\hline Brent & $\begin{array}{l}\text { Tokyngton } \\
\text { Park }\end{array}$ & $\begin{array}{l}51^{\circ} 32^{\prime} 50.6^{\prime \prime} \mathrm{N} \\
0^{\circ} 16^{\prime} 15.8^{\prime \prime} \mathrm{W}\end{array}$ & $\begin{array}{l}51^{\circ} 32^{\prime} 54.8^{\prime \prime} \mathrm{N} \\
0^{\circ} 16^{\prime} 09.5^{\prime \prime} \mathrm{W}\end{array}$ & 2003 & 28.8 & 69 & $\begin{array}{l}\text { Impoundments } \\
\text { and habitat } \\
\text { degradation }\end{array}$ & $\begin{array}{l}\text { Recycling of concrete to } \\
\text { restabilise banks, } \\
\text { remeandering and creation } \\
\text { of backwaters }\end{array}$ \\
\hline Hogsmill & $\begin{array}{l}\text { Green } \\
\text { Lane }\end{array}$ & $\begin{array}{l}51^{\circ} 21^{\prime} 22.7^{\prime \prime} \mathrm{N} \\
0^{\circ} 15^{\prime} 27.9^{\prime \prime} \mathrm{W}\end{array}$ & $\begin{array}{l}51^{\circ} 21^{\prime} 28.4^{\prime \prime} \mathrm{N} \\
0^{\circ} 15^{\prime} 41.1^{\prime \prime} \mathrm{W}\end{array}$ & 2014 & 9.9 & 39 & $\begin{array}{l}\text { Fish pass } \\
\text { obstructions, weirs } \\
\text { and sewage }\end{array}$ & $\begin{array}{l}\text { Weir removals, creation of } \\
\text { pools and riffles, channel } \\
\text { narrowing }\end{array}$ \\
\hline Pool & $\begin{array}{l}\text { Bell } \\
\text { Green }\end{array}$ & $\begin{array}{l}51^{\circ} 26^{\prime} 16.6^{\prime \prime} \mathrm{N} \\
0^{\circ} 01^{\prime} 38.1^{\prime \prime} \mathrm{W}\end{array}$ & $\begin{array}{l}51^{\circ} 26^{\prime} 21.5^{\prime \prime} \mathrm{N} \\
0^{\circ} 01^{\prime} 35.3^{\prime \prime} \mathrm{W}\end{array}$ & 2012 & 5.1 & 57 & $\begin{array}{c}\text { Culverting, } \\
\text { vegetation loss }\end{array}$ & Berms and redirecting flows \\
\hline Ravensbourne & $\begin{array}{l}\text { Ladywell } \\
\text { Fields }\end{array}$ & $\begin{array}{l}51^{\circ} 27^{\prime} 05.3^{\prime \prime} \mathrm{N} \\
0^{\circ} 01^{\prime} 25.4^{\prime \prime} \mathrm{W}\end{array}$ & $\begin{array}{l}51^{\circ} 27^{\prime} 10.5^{\prime \prime} \mathrm{N} \\
0^{\circ} 01^{\prime} 11.9^{\prime \prime} \mathrm{W}\end{array}$ & 2008 & 17.4 & 51 & $\begin{array}{l}\text { Channelisation and } \\
\text { culverting }\end{array}$ & Remeandering through park \\
\hline Wandle & Carshalton & $\begin{array}{l}51^{\circ} 22^{\prime} 11.1^{\prime \prime} \mathrm{N} \\
0^{\circ} 09^{\prime} 37.2^{\prime \prime} \mathrm{W}\end{array}$ & $\begin{array}{l}51^{\circ} 22^{\prime} 04.7^{\prime \prime} \mathrm{N} \\
0^{\circ} 09^{\prime} 44.3^{\prime \prime} \mathrm{W}\end{array}$ & 2015 & 14.0 & 47 & $\begin{array}{l}\text { Impoundment, } \\
\text { weirs, low flow } \\
\text { and oxygen levels }\end{array}$ & $\begin{array}{l}\text { Lowering of weirs and } \\
\text { improved fish passage }\end{array}$ \\
\hline
\end{tabular}


Table 2. A summary of physical habitat characteristics across the study rivers. Measurements were made after fish collections at each study reach (wetted width $(n=5)$, depth $(n=25)$ and velocity $(n=25)$; (see [42] for detailed methods). Values in parentheses denote one standard error. Significant differences between restored and unrestored reaches are in bold; differences among rivers are indicated by letter groupings (i.e., the same letters displayed denote no statistical differences between rivers, while different letters denote statistical differences between rivers). These physical habitat characteristics did differ across the study rivers and between select restored and unrestored reaches but still provided conditions that satisfied the requirements for resident fish species [40]. Physical habitat characteristics across the sites during the study period are provided in Supplementary Materials, Table S1.

\begin{tabular}{|c|c|c|c|c|}
\hline River & Reach & Wetted Width (m) & Depth (m) & Velocity $\left(\mathrm{m} \mathrm{s}^{-1}\right)$ \\
\hline \multirow[t]{2}{*}{ Brent } & Restored & $6.19^{d}(0.74)$ & $0.28^{\mathrm{a}, \mathrm{e}}(0.05)$ & $0.18^{a}(0.03)$ \\
\hline & Unrestored & $6.03^{d}(0.60)$ & $0.21^{\mathrm{a}, \mathrm{e}}(0.02)$ & $0.37^{\mathrm{a}}(0.03)$ \\
\hline \multirow[t]{2}{*}{ Hogsmill } & Restored & $4.11^{\mathrm{c}}(0.11)$ & $0.06^{b}(0.01)$ & $0.38^{a}(0.04)$ \\
\hline & Unrestored & $3.30^{c}(0.06)$ & $0.25^{b}(0.05)$ & $0.12^{a}(0.02)$ \\
\hline \multirow[t]{2}{*}{ Pool } & Restored & $6.12^{\mathrm{a}, \mathrm{d}}(0.24)$ & $0.18^{d}(0.02)$ & $0.14^{\mathrm{b}}(0.01)$ \\
\hline & Unrestored & $6.82^{\mathrm{a}, \mathrm{d}}(0.05)$ & $0.40^{d}(0.02)$ & $0.08^{b}(0.0003)$ \\
\hline \multirow[t]{2}{*}{ Ravensbourne } & Restored & $6.70^{\mathrm{a}}(0.22)$ & $0.26^{\mathrm{a}}(0.02)$ & $0.17^{\mathrm{c}}(0.02)$ \\
\hline & Unrestored & $6.88^{a}(0.22)$ & $0.33^{\mathrm{a}}(0.03)$ & $0.23^{\mathrm{c}}(0.01)$ \\
\hline \multirow[t]{2}{*}{ Wandle } & Restored & $2.90^{b}(0.16)$ & $0.22^{\mathrm{c}, \mathrm{e}, \mathrm{b}}(0.02)$ & $0.29^{\mathrm{d}, \mathrm{c}}(0.04)$ \\
\hline & Unrestored & $3.74^{\mathrm{b}}(0.13)$ & $0.16^{\mathrm{c}, \mathrm{e}, \mathrm{b}}(0.01)$ & $0.24^{\mathrm{d}, \mathrm{c}}(0.03)$ \\
\hline
\end{tabular}

\subsection{Data Analysis}

Statistical analysis of physical reach characteristics was undertaken using a 2-way ANOVA on ranks followed by a Tukey's post hoc test. Estimated fish abundances were calculated using the Carle and Strub [43] catch depletion method. Comparisons among the study rivers and between reach types were assessed with $95 \%$ confidence intervals. Catch density (individuals per $\mathrm{m}^{2}$ ) based on Carle and Strub estimates was calculated for all reaches. These analyses were carried out using the fisheries stock assessment (FSA) package [44] in R.

Individual fish weights were recorded in the field where possible. The remaining fish were estimated using additional datasets and equations to establish length-weight regressions (Supplementary Materials, Table S2). Total biomass per $\mathrm{m}^{2}$ was calculated across all study reaches.

Overall community structure was examined using non-metric multidimensional scaling (NMDS) using measures of Bray-Curtis similarity. NMDS uses ordinations to determine relationships between communities for population estimates and biomass across reaches by ranking data on a site and species similarity matrix. Biplots of the 1st and 2nd NMDS axis were created in R (ggplot2; [45]) to visualise overall patterns among the study rivers and between restored and unrestored reaches. Analysis of similarity (2-way ANOSIM) was then used to assess if similarities of fish community structure (density and biomass) were related to either river or reach type. Ordinations were performed using the vegan package in R [46].

\section{Results}

\subsection{Fish Density and Biomass}

The total density of fish (individuals $\left./ \mathrm{m}^{2}\right)$ across all rivers was $2.07 \mathrm{fish} / \mathrm{m}^{2}(95 \%$ CI: 1.85-2.28) for restored sites and $1.28 \mathrm{fish} / \mathrm{m}^{2}$ (95\% CI: 1.09-1.47) for unrestored sites (Figure 2). Significantly more fish were caught at restored reaches than unrestored reaches, as indicated by the non-overlapping $95 \%$ confidence intervals. These results were primarily driven by the catch at the Hogsmill, Pool and Wandle restored reaches (Figure 2; Table 3). Conversely, more fish were caught at the unrestored River Brent reach when compared with its restored counterpart. Across all the study rivers, differences were primarily attributed 
to a dominance of European bullhead (Cottus gobio L.) across restored and unrestored sites (Table 3; Supplementary Materials; Table S2).

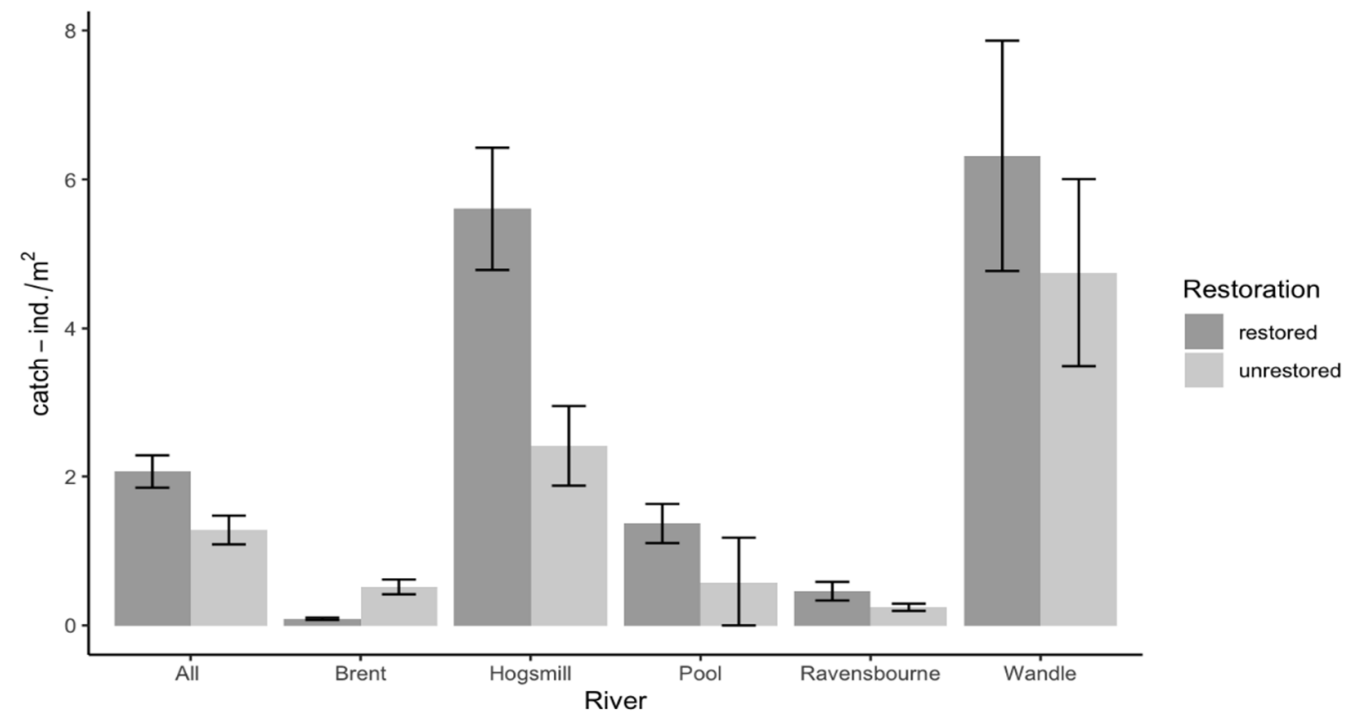

Figure 2. All catch $\left(\right.$ fish $/ \mathrm{m}^{2}$ ) for all sites, separated by river and reach. Estimates were calculated using the Carle and Strub method using 3-pass depletion electrofishing catches. Error bars are 95\% confidence intervals. The data displayed in the "All" column shows all catch across the total area sampled in the restored and unrestored study reaches.

Table 3. All catch (fish $/ \mathrm{m}^{2}$ ) for species across rivers and reaches, comprising all individuals caught across three 25-metre sweeps. Estimates were calculated using the Carle and Strub method and 3-pass depletion electrofishing.

\begin{tabular}{|c|c|c|c|c|c|c|c|c|c|c|c|}
\hline River & Reach & $\begin{array}{c}\text { Estimated } \\
\text { Catch } \\
\left.\text { (Ind. } / \mathrm{m}^{2}\right)\end{array}$ & Bullhead & Dace & Eel & Minnow & Perch & Roach & Stickleback & $\begin{array}{l}\text { Stone } \\
\text { Loach }\end{array}$ & $\begin{array}{c}\text { Brown } \\
\text { Trout }\end{array}$ \\
\hline \multirow[t]{2}{*}{ Brent } & Restored & 0.09 & 0.00 & 0.00 & 0.01 & 0.00 & 0.00 & 0.00 & 0.08 & 0.00 & 0.00 \\
\hline & Unrestored & 0.52 & 0.00 & 0.00 & 0.12 & 0.00 & 0.00 & 0.00 & 0.39 & 0.00 & 0.00 \\
\hline \multirow[t]{2}{*}{ Hogsmill } & Restored & 5.61 & 3.27 & 0.00 & 0.00 & 2.17 & 0.00 & 0.00 & 0.16 & 0.00 & 0.00 \\
\hline & Unrestored & 2.41 & 2.23 & 0.00 & 0.00 & 0.11 & 0.00 & 0.00 & 0.00 & 0.00 & 0.00 \\
\hline \multirow[t]{2}{*}{ Pool } & Restored & 1.37 & 0.00 & 0.00 & 0.01 & 0.00 & 0.00 & 0.00 & 0.69 & 0.72 & 0.00 \\
\hline & Unrestored & 0.57 & 0.00 & 0.23 & 0.00 & 0.00 & 0.01 & 0.01 & 0.22 & 0.08 & 0.00 \\
\hline \multirow[t]{2}{*}{ Ravensbourne } & Restored & 0.46 & 0.00 & 0.04 & 0.02 & 0.00 & 0.00 & 0.00 & 0.19 & 0.00 & 0.00 \\
\hline & Unrestored & 0.24 & 0.00 & 0.00 & 0.00 & 0.00 & 0.00 & 0.00 & 0.14 & 0.10 & 0.00 \\
\hline \multirow[t]{2}{*}{ Wandle } & Restored & 6.32 & 6.30 & 0.00 & 0.00 & 0.00 & 0.00 & 0.00 & 0.03 & 0.00 & 0.17 \\
\hline & Unrestored & 4.74 & 4.44 & 0.00 & 0.00 & 0.00 & 0.00 & 0.00 & 0.14 & 0.00 & 0.01 \\
\hline
\end{tabular}

Across all rivers, the total fish biomass was $57.17 \mathrm{~g} / \mathrm{m}^{2}$ at restored sites and $25.51 \mathrm{~g} / \mathrm{m}^{2}$ at unrestored sites (Figure 3). The biomass for reaches differed, with the lowest values recorded at the Brent restored reach $0.17 \mathrm{~g} / \mathrm{m}^{2}$, and the highest value recorded at the Wandle restored reach $37.71 \mathrm{~g} / \mathrm{m}^{2}$ (Figure 3; Table 4). The highest biomass values at restored reaches were largely driven by brown trout at the restored reach of the River Wandle. The biomass at this restored site was driven by the presence of 12 adult brown trout, accounting for a total mass of $29.72 \mathrm{~g} / \mathrm{m}^{2}$ (Table 4). The restored Wandle reach also recorded the highest biomass for bullhead. The Pool and Brent were the only rivers where overall biomass values were greater at unrestored sites when compared with restored sites (Table 4), driven by common dace (Leuciscus leuciscus L.) and European eels (Anguilla anguilla L.), respectively. Stone loach (Barbatula barbatula L.) was only found in the Ravensbourne and Pool, with higher biomass values recorded at restored reaches. At an individual scale, both total length and biomass for resident fish species were similar between restored and unrestored reaches (Figure 4). 


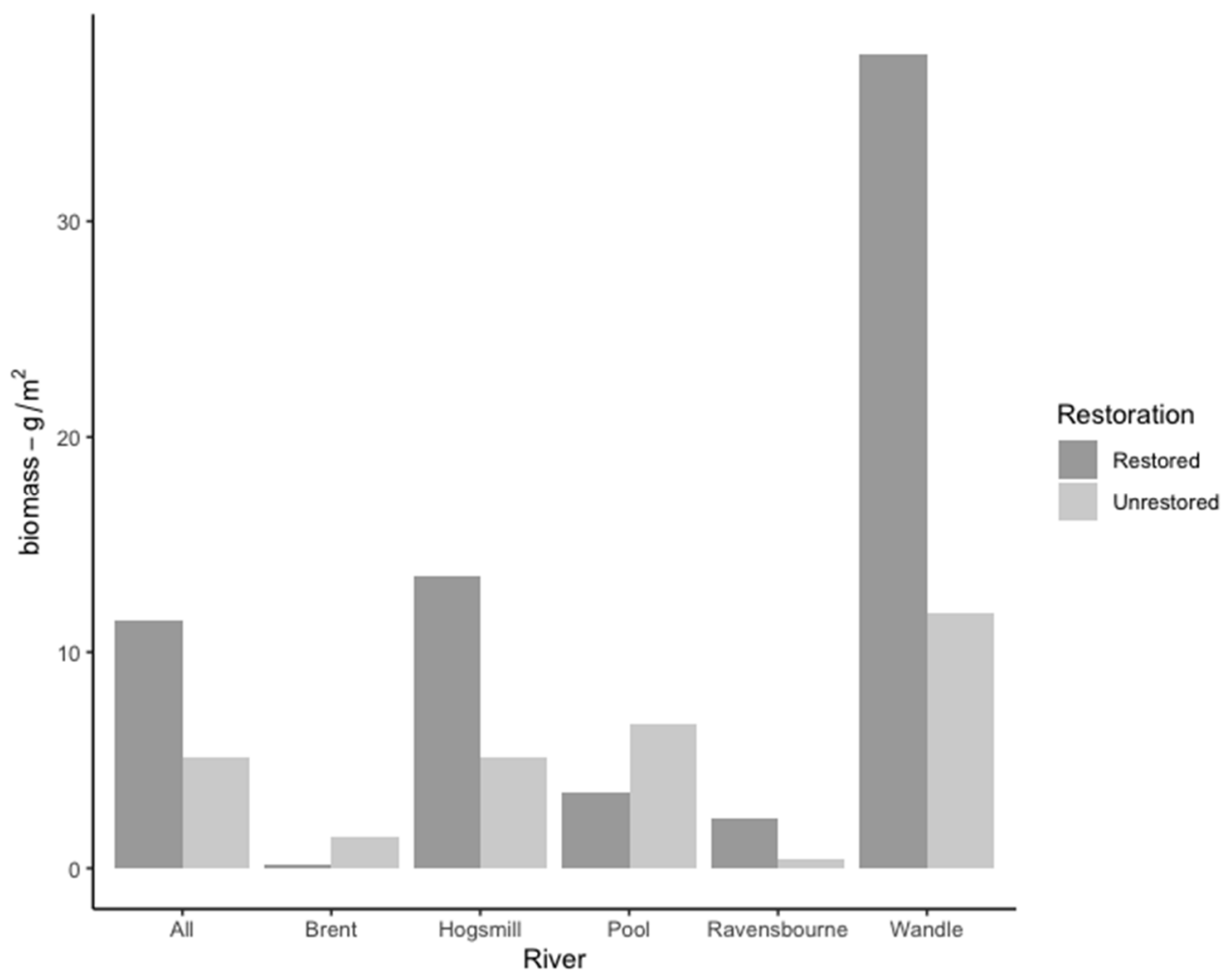

Figure 3. All fish biomass $\left(\mathrm{g} / \mathrm{m}^{2}\right)$ for all sites, separated by river and reach. The data displayed in the "All" column shows the sum of all fish biomass caught across the total area sampled in the restored and unrestored study reaches.

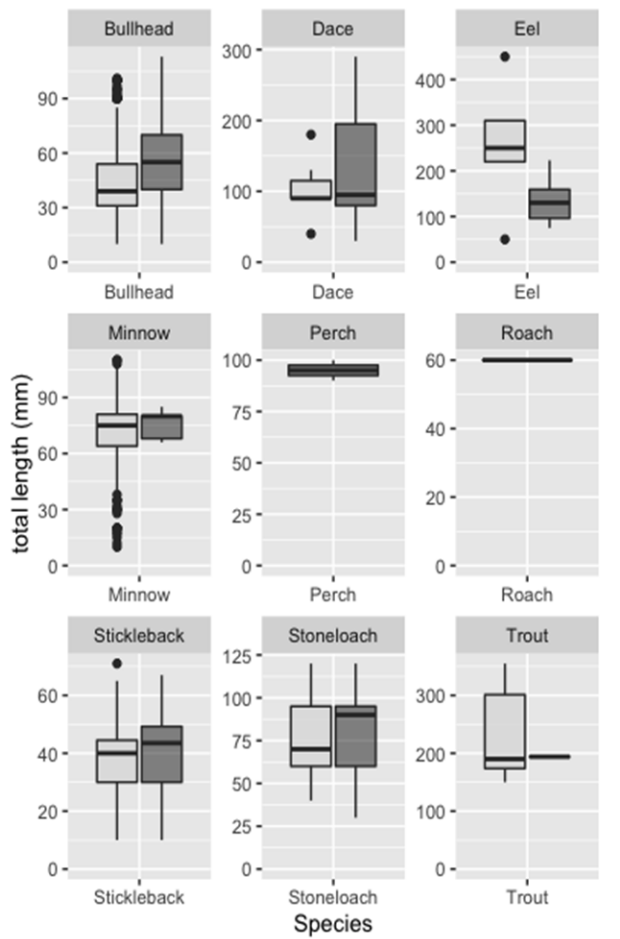

(a)

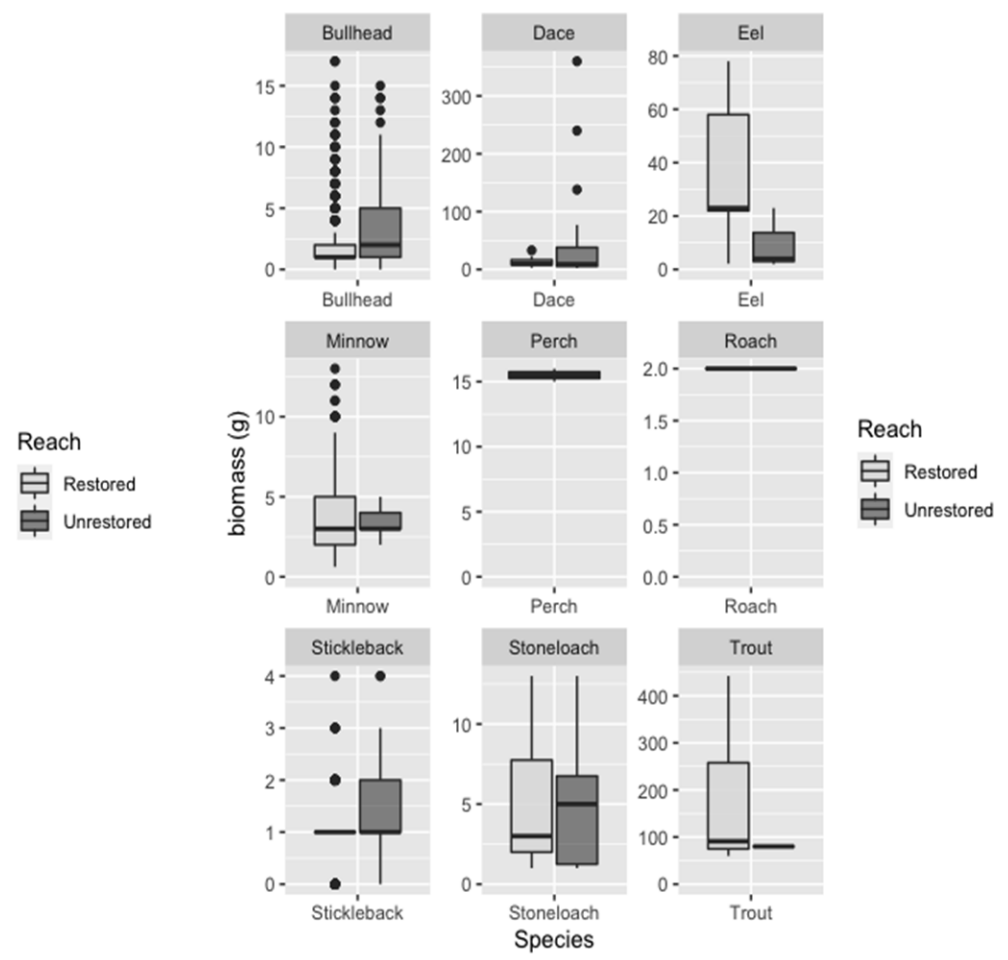

(b)

Figure 4. (a) Individual total length ( $\mathrm{mm}$ ) and (b) individual biomass (g) across 9 different species collected during the study. 
Table 4. The total fish biomass $\left(\mathrm{g} / \mathrm{m}^{2}\right)$ for species across rivers and reaches, comprising all individuals caught across three 25-metre sweeps.

\begin{tabular}{|c|c|c|c|c|c|c|c|c|c|c|c|}
\hline River & Reach & $\begin{array}{c}\text { Total } \\
\text { Biomass } \\
\left(\mathrm{g} / \mathrm{m}^{2}\right)\end{array}$ & Bullhead & Dace & Eel & Minnow & Perch & Roach & Stickleback & $\begin{array}{l}\text { Stone } \\
\text { Loach }\end{array}$ & $\begin{array}{c}\text { Brown } \\
\text { Trout }\end{array}$ \\
\hline \multirow{2}{*}{ Brent } & Restored & 0.17 & 0.00 & 0.00 & 0.01 & 0.00 & 0.00 & 0.00 & 0.16 & 0.00 & 0.00 \\
\hline & Unrestored & 1.48 & 0.00 & 0.00 & 1.02 & 0.00 & 0.00 & 0.00 & 0.46 & 0.00 & 0.00 \\
\hline \multirow[t]{2}{*}{ Hogsmill } & Restored & 13.52 & 6.17 & 0.00 & 0.00 & 7.27 & 0.00 & 0.00 & 0.08 & 0.00 & 0.00 \\
\hline & Unrestored & 5.16 & 4.87 & 0.00 & 0.00 & 0.29 & 0.00 & 0.00 & 0.00 & 0.00 & 0.00 \\
\hline \multirow[t]{2}{*}{ Pool } & Restored & 3.48 & 0.00 & 0.00 & 0.38 & 0.00 & 0.00 & 0.00 & 0.41 & 2.69 & 0.00 \\
\hline & Unrestored & 6.67 & 0.00 & 5.86 & 0.00 & 0.00 & 0.18 & 0.01 & 0.09 & 0.53 & 0.00 \\
\hline \multirow[t]{2}{*}{ Ravensbourne } & Restored & 2.29 & 0.00 & 0.57 & 0.73 & 0.00 & 0.00 & 0.00 & 0.17 & 0.82 & 0.00 \\
\hline & Unrestored & 0.42 & 0.00 & 0.00 & 0.00 & 0.00 & 0.00 & 0.00 & 0.12 & 0.31 & 0.00 \\
\hline \multirow[t]{2}{*}{ Wandle } & Restored & 37.71 & 7.93 & 0.00 & 0.00 & 0.00 & 0.00 & 0.00 & 0.06 & 0.00 & 29.72 \\
\hline & Unrestored & 11.78 & 10.66 & 0.00 & 0.00 & 0.00 & 0.00 & 0.00 & 0.26 & 0.00 & 0.86 \\
\hline
\end{tabular}

\subsection{Community Structure}

Non-metric multidimensional scaling (NMDS) plots demonstrated non-random associations across the study reaches for both density (stress $=9.78 \times 10^{-5}$; Figure 5) and biomass (stress $=0.007$; Figure 5). However, ANOSIM results failed to support the hypothesis that community structure was related to reach type (density: reach $R=-0.14$, significance $=0.91$; biomass: reach $R=-0.1$, significance $=0.87$ ). The community structure across the study rivers differed significantly (density: $R=0.59$, significance $=0.01$; biomass: $\mathrm{R}=0.47$, significance $=0.007$ ). Visual inspection of both the density and biomass biplots showed that study reaches in the Wandle and Hogsmill tended to be more similar to each other than the other study reaches, likely driven by bullhead found in these rivers.

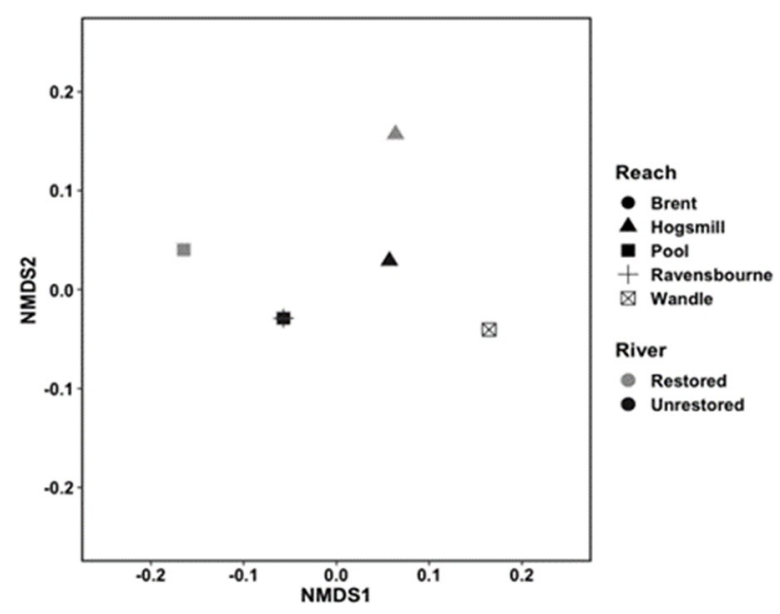

(a)

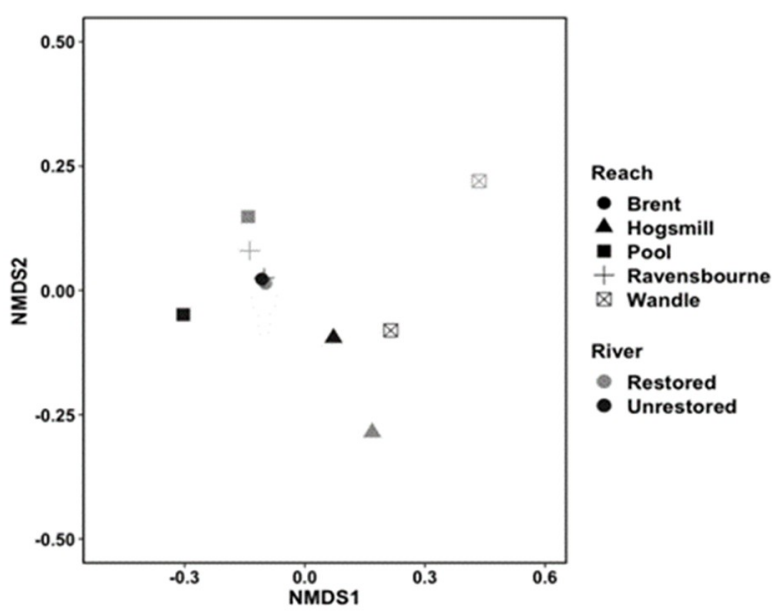

(b)

Figure 5. Plots of non-metric multidimensional scaling (NMDS), highlighting community clustering between rivers and reaches for (a) density and (b) biomass.

\section{Discussion}

Our findings show that fish density and biomass were generally higher at restored reaches, with bullhead and brown trout driving much of the differences observed among the rivers (i.e., Wandle and Hogsmill). The River Wandle restored reach recorded the highest biomass of all sites, owing to the presence of brown trout, likely influenced by a past stocking programme [47]. In 2001, the Wandle Trust launched the 'Trout in the Classroom' initiative, which continued for 12 years and resulted in the establishment of reproducing and self-sustaining trout populations [48]. Higher numbers of brown trout, which are a Priority Species under the UK Post-2010 Biodiversity Framework and are intolerant of low oxygen concentrations, suggest that this species may be preferentially 
selecting habitats with improved conditions (e.g., water quality) created as a result of the restoration work. Similar behaviours have been observed for other species, notably stone loach and bullhead, which can respond to measures at restored reaches-for example, to the installation of artificial riffles [34]. Such behaviour may explain higher bullhead densities recorded at the Wandle and Hogsmill restored sites in this study. The European bullhead is currently listed on the International Union for Conservation of Nature (IUCN) Red List of Threatened Species [49], Annex II of the European Commission Habitats Directive [50] and Special Area of Conservation (SAC) Annex II species and are thought to be in decline. At other sites, it is possible that the reach-scale restoration activities are not proving effective in achieving desired environmental outcomes, as, for example, studies have found that stabilising banks can prevent them from migrating and, in turn, negatively impact habitat quality [51,52]. However, our findings suggest to some degree that there are clear merits to directed, reach-scale habitat creation projects.

Despite these results, fish community structure likely reflected river-specific conditions rather than improvements associated with reach-scale restoration practices. This is clearly demonstrated when comparing the presence of bullhead at the Hogsmill and Wandle with the stone loach at the Pool and Ravensbourne. While both fish occupy benthic habitats, bullhead tends to require better water quality and cooler water temperatures when compared to stone loach [53-55]. It is possible that the environmental conditions at the Hogsmill and Wandle already provide more suitable habitats for bullhead and brown trout, respectively. However, a more detailed examination of river-specific habitat preferences and thermal acclimation for these fish would be needed to evaluate this further. Regardless, these patterns do strongly support the notion that one-size-fits-all river restoration practices are unlikely to support universal improvements in fish biodiversity [56,57].

The ecology of urban rivers is generally influenced by channel alterations (including the riparian zone), water quality and sediment quantity and quality [58]. Considering the varying degrees of anthropogenic alterations observed in these river catchments, it is perhaps not surprising that reach-scale restoration did not provide a more substantial change to overall fish biodiversity. The ecology of these rivers is characteristic of urban systems, which are influenced by flow homogeneity and poor water quality $[39,41]$. While improvements to flow heterogeneity and the creation of habitats are promising, these measures will have limited success without being paired with sustaining improvements to overall water quality.

The importance of managing rivers to improve fluvial habitats at appropriate scales has been widely documented [59,60]. Studies have highlighted the importance of restoring watershed processes and connectivity, as well as protecting high-quality habitats prior to carrying out in-stream habitat restoration projects [28]. If limiting factors for improving biodiversity are identified and addressed, it is much more likely that ecosystems will respond effectively. Too often, it is assumed that structural modifications will bring about improvements in water quality or ecological diversity rather than targeting the limiting factor itself. Hydrological and sediment regimes, as well as aquatic habitats and species, are influenced by ecosystem processes that occur at the regional, watershed and reach scale $[58,59,61]$. Therefore, adopting reach-scale approaches may not necessarily elicit ecological recovery unless the projects are nested and distributed across entire catchments. Future work should take account of the 'REstoring rivers FOR effective catchment Management' (REFORM) recommendations, which highlight the importance of physical processes operating at different temporal and spatial scales, as well as riparian and flood ecosystems that influence river morphodynamics and ecology [62].

Although a high number of initiatives which monitor river restoration project efficiencies have been reported [63], mitigation projects are often dominated by approaches that are not scientifically robust and lack the before-after-control-impact (BACI) data needed to monitor long-term restoration benefits and inform future works [64,65]. Given the lack of BACI data available to appraise river restoration success $[66,67]$, there is a great need to define goals for urban river restoration that consider structural and functional objectives. 
Urban catchments dominated by physically modified channels and high nutrient inputs are likely to require longer-term and catchment-scale management approaches, such as those outlined for the River Wandle [47]. In this respect, creating small patches of favourable environments for fish will likely lead to localised aggregation of species rather than elicit ecological improvements [35]. Thus, we advocate for holistic BACI approaches both to further understand the anthropogenic factors driving these pressures and to generate repeatable science needed for effective and sustainable river restoration.

While our results show that reach-scale river restoration can lead to localised increases in fish density and biomass at reach scales, this is likely due to the aggregation of fish utilising preferential habitats within a larger system characterised by longitudinal disconnectivity, geomorphological change, flow homogeneity and poor water quality. The question of whether reach-scale restoration provides a marginally better place to live within an urban river is posed and supported here and has been documented in other studies. Interpretations of the results of this study highlight the importance of designing ecologically focused river restoration strategies which target restoring catchment connectivity, improving water quality and understanding the ecological functions and life-cycle traits of fish to create habitats suitable for a wide array of species.

Supplementary Materials: The following are available online at https:/ /www.mdpi.com/article/10 .3390/w13162170/s1, Table S1: Physical habitat characteristics, Table S2: Fish survey data.

Author Contributions: Conceptualisation, A.M.L., M.A.C. and N.R.B., methodology, A.M.L., M.A.C. and N.R.B.; field investigation, A.M.L., D.D.A.C., E.G.P., M.A.C. and N.R.B.; formal analysis, A.M.L., M.A.C. and D.D.A.C.; data curation, A.M.L.; writing-original draft preparation, A.M.L.; writingreview and editing, M.A.C., D.D.A.C. and E.G.P. All authors have read and agreed to the published version of the manuscript.

Funding: This research was funded by the Natural Environment Research Council and London DTP, grant reference NE/L002485/1. The funders had no role in study design, data collection and analysis, decision to publish or preparation of the manuscript.

Institutional Review Board Statement: No institutional approval was required for this work. All fish sampling was approved by the Environment Agency.

Informed Consent Statement: Not applicable.

Data Availability Statement: The data presented in this study are openly available in FigShare.

Acknowledgments: Thanks go to the fieldwork assistants who helped with the electric fishing surveys. Thanks to Toby Hull and Chris Gardner at the South East Rivers Trust for offering up their in-depth knowledge and expertise of the River Wandle and Hogsmill restoration projects. Thanks are extended to the Environment Agency for providing background fish data and licenses for fish surveys.

Conflicts of Interest: The authors declare no conflict of interest.

\section{References}

1. Helms, B.S.; Feminella, J.W.; Pan, S. Detection of biotic responses to urbanization using fish assemblages from small streams of western Georgia, USA. Urban Ecosyst. 2005, 8, 39-57. [CrossRef]

2. Utz, R.M.; Hilderbrand, R.H.; Raesly, R.L. Regional differences in patterns of fish species loss with changing land use. Biol. Conserv. 2010, 143, 688-699. [CrossRef]

3. Czeglédi, I.; Kern, B.; Tóth, R.; Seress, G.; Erős, T. Impacts of Urbanization on Stream Fish Assemblages: The Role of the Species Pool and the Local Environment. Environ. Front. Ecol. Evol. 2020, 8, 137. [CrossRef]

4. Walsh, C.J.; Roy, A.H.; Feminella, J.W.; Cottingham, P.D.; Groffman, P.M.; Morgan, R.P. The urban stream syndrome: Current knowledge and the search for a cure. J. N. Am. Benthol. Soc. 2005, 24, 706-723. [CrossRef]

5. Wenger, S.J.; Roy, A.H.; Jackson, C.R.; Bernhardt, E.S.; Carter, T.L.; Filoso, S.; Gibson, C.A.; Hession, W.C.; Kaushal, S.S.; Martí, E.; et al. Twenty-six key research questions in urban stream ecology: An assessment of the state of the science. J. N. Am. Benthol. Soc. 2009, 28, 1080-1098. [CrossRef]

6. Booth, D.B.; Roy, A.H.; Smith, B.; Capps, K.A. Global perspectives on the urban stream syndrome. Freshw. Sci. 2016, 35, 412-420. [CrossRef] 
7. Rieck, L.O.; Sullivan, S.M.P. Coupled fish-hydrogeomorphic responses to urbanization in streams of Columbus, Ohio, USA. PLoS ONE 2020, 15, e0234303. [CrossRef]

8. Carter, M.; England, J. Freshwater fish in London's rivers. Lond. Nat. 2004, 83, 77-85.

9. Schoonover, J.; Lockaby, B.G.; Pan, S. Changes in chemical and physical properties of stream water across an urban-rural gradient in western Georgia. Urban Ecosyst. 2005, 8, 107-124. [CrossRef]

10. Kim, J.J.; Atique, U.; An, K.G. Long-term ecological health assessment of a restored urban stream based on chemical water quality, physical habitat conditions and biological integrity. Water 2019, 11, 114. [CrossRef]

11. Pecorelli, J.P.; Macphie, K.H.; Hebditch, C.; Clifton-Dey, D.R.J.; Thornhill, I.; Debney, A.J. Using citizen science to improve the conservation of the European Eel in the Thames River Basin District. Freshw. Sci. 2019, 38, 281-291. [CrossRef]

12. Favaro, C.; Moore, J.W.; Reynolds, J.D.; Beakes, M.P. Potential loss and rehabilitation of stream longitudinal connectivity: Fish populations in urban streams with culverts. Can. J. Fish. Aquat. Sci. 2014, 71, 1805-1816. [CrossRef]

13. Palmer, M.A.; Allan, J.D.; Meyer, J.L.; Bernhardt, E.S. River restoration in the twenty-first century: Data and experiential future efforts. Restor. Ecol. 2007, 15, 472-481. [CrossRef]

14. Wohl, E.; Lane, S.N.; Wilcox, A.C. The science and practice of river restoration. Water Resour. Res. 2015, 51, 5974-5997. [CrossRef]

15. Roni, P. Does river restoration increase fish abundance and survival or concentrate fish? The effects of project scale, location, and fish life history. Fisheries 2019, 44, 7-19. [CrossRef]

16. Hohensinner, S.; Hauer, C.; Muhar, S. River morphology, channelization, and habitat restoration. In Riverine Ecosystem Management; Schmutz, S., Sendzimir, J., Eds.; Springer: Cham, Switzerland, 2018; Volume 8, pp. 41-65. [CrossRef]

17. Hughes, F.M.R.; Colston, A.; Mountford, J.O. Restoring Riparian Ecosystems: The Challenge of Accommodating Variability and Designing Restoration Trajectories. Ecol. Soc. 2005, 10, 12. [CrossRef]

18. Palmer, M.A.; Ambrose, R.F.; Poff, N.L. Ecological theory and community restoration ecology. Restor. Ecol. 1997, 5, 291-300. [CrossRef]

19. Grabowski, R.C.; Gurnell, A.M.; Burgess-Gamble, L.; England, J.; Holland, D.; Klaar, M.J.; Morrissey, I.; Uttley, C.; Wharton, G. The current state of the use of large wood in river restoration and management. Water Environ. J. 2019, 33, 366-377. [CrossRef]

20. Kondolf, G.M. River restoration and meanders. J. Ecol. Soc. 2006, 11, 42. [CrossRef]

21. Staentzel, C.; Kondolf, G.M.; Schmitt, L.; Combroux, I.; Barillier, A.; Beisel, J. Restoring fluvial forms and processes by gravel augmentation or bank erosion below dams: A systematic review of ecological responses. Sci. Total. Environ. 2020, 706, 135743. [CrossRef]

22. Bukaveckas, P.A. Effects of channel restoration on water velocity, transient storage, and nutrient uptake in a channelized stream. Environ. Sci. Technol. 2007, 41, 1570-1576. [CrossRef] [PubMed]

23. Pander, J.; Mueller, M.; Geist, J.A. Comparison of Four Stream Substratum Restoration Techniques Concerning Interstitial Conditions and Downstream Effects. River Res. Appl. 2014, 31, 239-255. [CrossRef]

24. Birnie-Gauvin, K.; Candee, M.M.; Baktoft, H.; Larsen, M.H.; Koed, A.; Aarestrup, K. River connectivity reestablished: Effects and implications of six weir removals on brown trout smolt migration. River Restor. Appl. 2018, 34, 548-554. [CrossRef]

25. Pini Prato, E.; Comoglio, C.; Calles, O. A simple management tool for planning the restoration of river longitudinal connectivity at watershed level: Priority indices for fish passes. J. Appl. Ichthyol. 2011, 27, 73-79. [CrossRef]

26. Wang, Y.; Wai, O.W.; Chen, Q. Experimental and Numerical Studies on Deflector Configuration in Straight Flood Channel for Heterogeneous Flow Enhancement and Fish Habitat Improvements. Ecol. Eng. 2020, 156, 105964. [CrossRef]

27. Marttila, M.; Louhi, P.; Huusko, A.; Vehanen, T.; Mäki-Petäys, A.; Erkinaro, J.; Syrjänen, J.; Muotka, T. Synthesis of habitat restoration impacts on young-of-the-year salmonids in boreal rivers. Rev. Fish Biol. Fish. 2019, 513-527. [CrossRef]

28. Roni, P.; Hanson, K.; Beechie, T. Global review of the physical and biological effectiveness of stream habitat rehabilitation techniques. N. Am. J. Fish. Manag. 2008, 28, 856-890. [CrossRef]

29. Stewart, G.B.; Bayliss, H.R.; Showler, D.A.; Sutherland, W.J.; Pullin, A.S. Effectiveness of engineered in-stream structure mitigation measures to increase salmonid abundance: A systematic review. Ecol. Appl. 2009, 19, 931-941. [CrossRef] [PubMed]

30. Whiteway, S.L.; Biron, P.M.; Zimmermann, A.; Venter, O.; Grant, J.W.A. Do in-stream restoration structures enhance salmonid abundance? A meta-analysis. Can. J. Fish. Aquat. Sci. 2010, 67, 831-841. [CrossRef]

31. Lorenz, A.W.; Stoll, S.; Sundermann, A.; Haase, P. Do adult and YOY fish benefit from river restoration measures? Ecol. Eng. 2013, 61, 174-181. [CrossRef]

32. Thompson, M.S.; Brooks, S.J.; Sayer, C.D.; Woodward, G.; Axmacher, J.C.; Perkins, D.M.; Gray, C. Large woody debris "rewilding" rapidly restores biodiversity in riverine food webs. J. Appl. Ecol. 2018, 55, 895-904. [CrossRef]

33. Richer, E.E.; Gates, E.A.; Kondratieff, M.C.; Herdrich, A.T. Modelling changes in trout habitat following stream restoration. River Restor. Appl. 2019, 35, 680-691. [CrossRef]

34. Pretty, J.L.; Harrison, S.S.C.; Shepherd, D.J.; Smith, C.; Hildrew, A.G.; Hey, R.D. River rehabilitation and fish populations: Assessing the benefit of instream structures. J. Appl. Ecol. 2003, 40, 251-265. [CrossRef]

35. Palmer, M.; Menninger, H.L.; Bernhardt, E. River restoration, habitat heterogeneity and biodiversity: A failure of theory or practice? Freshw. Biol. 2010, 55, 205-222. [CrossRef]

36. Roni, P.; Hanson, K.; Beechie, T.J.; Pess, G.R.; Pollock, M.M.; Bartley, D.M. Habitat rehabilitation for inland fisheries. In Global Review of Effectiveness and Guidance for Rehabilitation of Freshwater Ecosystems; No. 484; FAO: Rome, Italy, 2005. 
37. Speed, R.; Li, Y.; Tickner, D.; Huang, H.; Naiman, R.; Cao, J.; Lei, G.; Yu, L.; Sayers, P.; Zhao, Z.; et al. River Restoration: A Strategic Approach to Planning and Management; UNESCO: Paris, UK, 2016.

38. River Restoration Centre. UK Projects Map. Available online: https://www.therrc.co.uk/uk-projects-map (accessed on 1 May 2021).

39. Smith, B.; Chadwick, M.A. Litter decomposition in highly urbanized rivers: Influence of restoration on ecosystem function. Fundam. Appl. Limnol. 2014, 185, 7-18. [CrossRef]

40. Maitland, P.S. Keys to the Freshwater Fish of Britain and Ireland, with Notes on Their Distribution and Ecology; Freshwater Biological Association (FBA): Ambleside, UK, 2004.

41. Lavelle, A.M.; Bury, N.R.; O'Shea, F.T.; Chadwick, M.A. Influence of urban river restoration on nitrogen dynamics at the sediment-water interface. PLoS ONE 2019, 14, e0212690. [CrossRef]

42. Lavelle, A. Stream Ecosystem Responses to Restoration Across Urban Tributaries of the River Thames, London. Ph.D Thesis, Kings' College London, London, UK, 2019.

43. Carle, F.L.; Strub, M.R. A new method for estimating population size from removal data. Biometrics 1978, 34, 621-630. [CrossRef]

44. Ogle, D.H. Introductory Fisheries Analyses with R; Chapman \& Hall/ CRC: Boca Raton, FL, USA, 2016.

45. Wickham, H. ggplot2: Elegant Graphics for Data Analysis; Springer: New York, NY, USA, 2016.

46. Oksanen, J.; Blanchet, F.G.; Friendly, M.; Kindt, R.; Legendre, P.; McGlinn, D.; Minchin, P.R.; O'Hara, R.B.; Simpson, G.L.; Solymos, P.; et al. Vegan Community Ecology Package Version 2.5-7; R Development Core Team: Vienna, Austria, 2020.

47. Pike, T.; Bedford, C.; Davies, B.; Brown, D. A catchment Plan for the River Wandle. Wandle River Trust. 2014. Available online: https: //www.wandletrust.org/wp-content/uploads/2014/12/Wandle_Catchment_Plan_-_Sept_2014_-_full_document.pdf (accessed on 1 May 2021).

48. O'Brien, J. An Angler's Guide to the River Wandle; STR Design \& Print Limited: Carshalton, UK, 2018.

49. Freyhof, J. Cottus gobio (Errata Version Published in 2016). The IUCN Red List of Threatened Species 2011: e.T5445A97802083. Available online: https://www.iucnredlist.org/species/5445/97802083 (accessed on 1 August 2021).

50. Directive, H. Council Directive 92/43/EEC of 21 May 1992 on the conservation of natural habitats and of wild fauna and flora. Off. J. Eur. Union 1992, 206, 7-50.

51. Florsheim, J.L.; Mount, J.F.; Chin, A. Bank erosion as a desirable attribute of rivers. Bioscience 2008, 58, 519-529. [CrossRef]

52. Williams, R.D.; Bangen, S.; Gillies, E.; Kramer, N.; Moir, H.; Wheaton, J. Let the river erode! Enabling lateral migration increases geomorphic unit diversity. Sci. Total. Environ. 2021, 715, 136817. [CrossRef]

53. Elliott, A.A. comparison of thermal polygons for British freshwater teleosts. Freshw. Forum 2010, 5, 3.

54. Elliott, J.M.; Elliott, J.A. The critical thermal limits for the bullhead, Cottus gobio, from three populations in north-west England. Freshw. Biol. 1995, 33, 411-418. [CrossRef]

55. Coop, G.H.; Warrington, S.; De Bruine, Q. Comparison of diet in bullhead, Cottus gobio and stone loach, Barbatula barbatula in a small English lowland river. Folia Zool. 1994, 43, 171-176.

56. Angelopoulos, N.V.; Cowx, I.G.; Buijse, A.D. Integrated planning framework for successful river restoration projects: Upscaling lessons learnt from European case studies. Environ. Sci. Policy 2007, 76, 12-22. [CrossRef]

57. Rosgen, D. Natural Channel Design for River Restoration. Encycl. Water: Sci. Technol. Soc. 2019, 1-13. [CrossRef]

58. Gurnell, A.; Lee, M.; Souch, C. Urban rivers: Hydrology, geomorphology, ecology and opportunities for change. Geogr. Compass 2007, 1, 1118-1137. [CrossRef]

59. Beechie, T.J.; Sear, D.A.; Olden, J.D.; Pess, G.R.; Buffington, J.M.; Moir, H.; Roni, P.; Pollock, M.M. Process-based principles for restoring river ecosystems. Bioscience 2010, 60, 209-222. [CrossRef]

60. Kuemmerlen, M.; Reichert, P.; Siber, R.; Schuwirth, N. Ecological assessment of river networks: From reach to catchment scale. Sci. Total. Environ. 2019, 650, 1613-1627. [CrossRef]

61. Kail, J.; Hering, D. The influence of adjacent stream reaches on the local ecological status of central European mountain streams. River Res. Appl. 2009, 25, 537-550. [CrossRef]

62. REFORM: Restoring Rivers for Effective Catchment Management. Available online: reformrivers.eu (accessed on 1 July 2021).

63. Szałkiewicz, E.; Jusik, S.; Grygoruk, M. Status of and Perspectives on River Restoration in Europe: 310,000 Euros per Hectare of Restored River. Sustainability 2018, 10, 129. [CrossRef]

64. Feld, C.K.; Birk, S.; Bradley, D.C.; Hering, D.; Kail, J.; Marzin, A.; Melcher, A.; Nemitz, D.; Pedersen, M.L.; Pletterbauer, F.; et al. From natural to degraded rivers and back again: A test of restoration ecology theory and practice. Adv. Ecol. Res. 2011, 44, 119-209. [CrossRef]

65. Conner, M.M.; Saunders, W.C.; Bouwes, N.; Jordan, C. Evaluating impacts using a BACI design, ratios, and a Bayesian approach with a focus on restoration. Environ. Monit. Assess 2016, 188, 1-14. [CrossRef] [PubMed]

66. Al-Zankana, A.F.A.; Matheson, T.; Harper, D.M. How strong is the evidence-based on macroinvertebrate community responsesthat river restoration works? Ecohydrol. Hydrobiol. 2020, 20, 196-214. [CrossRef]

67. Morandi, B.; Piégay, H.; Lamouroux, N.; Vaudor, L. How is success or failure in river restoration projects evaluated? Feedback from French restoration projects. J. Environ. Manag. 2014, 137, 178-188. [CrossRef] [PubMed] 